\title{
Study of relationship between rework and labor productivity in Building Construction Projects
}

Ibrahim Mahamid (Main and Corresponding Author)

Civil Engineering Department, Faculty of Engineering, University of Prince Mugrin

414 99, Madinah (Saudi Arabia)

imahamid@ymail.com

Manuscript Code: 1449

Date of Acceptance/Reception: 24.12.2019/29.04.2019

DOI: $10.7764 /$ RDLC.19.1.30-41

\begin{abstract}
The objectives of this study included: (1) identifying the factors affecting construction labor productivity, (2) identifying the causes of rework in building projects, (3) addressing the relationship between labor productivity and rework using regression analysis based on data collected from building projects implemented in Palestine. The following steps were used in this study: (1) Questionnaire survey - stage 1: a questionnaire survey was carried out to identify the main factors affecting labor productivity and the main causes of rework on construction sites, (2) Questionnaire survey - stage 2: after identifying the significant causes of rework using factor analysis, a questionnaire survey was conducted to address the impact of these significant causes on labor productivity, (3) Prediction models: Data collected from 40 building construction projects were used to establish the regression models that describe the relation between rework and labor productivity on construction sites. The study concluded that the top factors affecting labor productivity are: lack of labor experience, payments delay, rework due to labor mistakes, lack of supervisor's experience and materials shortage. The study also found that the top five rework causes in building projects are: lack of manpower skills, non-compliance with specifications, frequent change orders, inadequate job planning, and inadequate coordination and integration. Using regression analysis for data collected from 40 building construction projects, three predictive models were developed. The models indicated a significant relation between rework cost and labor productivity i.e the higher the rework cost the lower the construction productivity. This study is the first one that investigated the relationship between construction productivity and rework in Palestine, and that is why it is very important. Results would be helpful for researchers and construction professionals.
\end{abstract}

Keywords: Productivity, rework, regression, prediction, buildings.

Introduction

Construction industry is one of the largest industries contributing to about $10 \%$ of the gross national product (GNP) in industrialized countries (Navon, 2005). However, it is complex and associated with high level of risk that leads to failure in terms of time, cost and quality. According to Chandrusha and Basha (2017), rework is a major factor contributing to this failure. Chandrusha \& Basha (2017) defined rework as "the unnecessary effort of redoing an activity that was inaccurately done the first time or the process by which an item is made to conform to the original requirement by completion or correction". They argued that rework seriously affect the performance and productivity aspects of construction projects and the problem of rework has been largely ignored by the construction industry. "Rework on construction sites" was concluded as a significant factor that influences the project performance in terms of time and cost (Mahamid, 2017; Enshassi et al., 2009; Kaming et al., 1997; Wasfy, 2010). However, "little is known about the background and consequently, rework remains an innate problem. The lack of attention to the root causes of rework seems to be a global phenomenon" (Chandrusha \& Basha, 2017).

On the other hand, labors considered as significant ingredients for construction projects as their costs account for between 30 and $50 \%$ of a project's total cost. They play a critical role in project success (Liu \& Ballard, 2008). Construction productivity is important because it influences time and cost objectives (Moselhi \& Khan, 2012). Construction industry is mostly defined as a labor-intensive industry. Therefore, labor productivity is critical for financial success of construction projects (El-Gohary \& Aziz, 2014). Due to the economic size of construction industry, an increase in labor productivity will improve the overall performance and increase the national income. Accordingly, attention should be paid to identify the factors affecting construction productivity to be able to improve it.

Previous research efforts had attempted to determine the factors that affecting construction productivity and rework. Yet, little or no attention has been directed towards the relationship between productivity and rework. Therefore, this paper is intended to address this important issue. Mainly, the objectives of this paper included: (1) identifying the factors affecting construction labor productivity, (2) identifying the causes of rework in building projects, (3) addressing the relationship between labor productivity and rework using regression analysis based on data collected from building projects implemented in Palestine. This study is the first one that investigated the relationship between 
construction productivity and rework in Palestine, and that is why this study is very important and will be helpful for researchers and professionals as well.

Previous studies

\section{Construction labor productivity}

Productivity is defined as ratio between input and output. Labor is the most important asset to a construction company. Despite many technological advances, construction industry continues to be a labor intensive. Labor costs account for between 30 and 50\% of a project's total cost. Therefore, labors are key of project success (Liu \& Ballard, 2008). Improving construction productivity is one of the main issues for construction parties to increase profit and to accomplish projects on time, cost and required quality. Thus, many previous studies were conducted to investigate the factors affecting construction labor productivity. Aynur et al. (2016) conducted a study to investigate the main factors affecting construction productivity from labors' perspective. Thirty-seven factors were identified and divided into four groups, namely: physical, economical, socio-physiological and organizational, factors. Nadia et al. (2017) reported that "residential construction involves labor-intensive tasks where workers are frequently confronted with problems that could lead to demotivation. Demotivation is caused not simply by a lack of motivators but the existence of certain situations that cause dissatisfaction and discourage individuals, therefore reducing overall productivity potential". Therefore, they did a field survey to determine the critical factors of manpower demotivation in residential construction projects in Jordan. The main factors are: working overtime and specifications and quality requirements.

Mahamid et al. (2014) addressed the main factors affecting labor productivity in public projects in Saudi Arabia. Lack of labor skills, poor communication between parties, payments delay, and bad working environment were among the top affecting factors. Robles et al. (2014) carried out a study to identify, analyze and rank factors affecting labor productivity in Spain. Findings revealed that the top five factors were: (1) late supply of materials, (2) poor project documents, (3) clear and daily task assignment; (4) shortage of equipment, (5) lack of labor skills. Montaser et al. (2018) found that the top factors affecting labor productivity in construction of pre-stressed concrete bridges were: design factor, equipment factor, execution and construction factor, external factor, financial factor, healthy and safety factor, labor factor, supervision factor, material factor, organization factor and other project factors.

Bekr (2016) indicated that the major factors affecting the labor productivity were: shortage of materials, shortage of equipment, inefficient equipment, poor planning, lack of supervisor's experience, inspection delay, rework due to workers mistakes and payments delay. Mahamid (2018) revealed that the most significant factors affecting labor productivity in road construction projects were: shortage of materials, inaccurate specifications and lack of labor experience. He also found a significant direct relationship between cost overrun and labor productivity in construction projects. Ghoddousi \& Hosseini (2012) conducted a questionnaire survey to address the main factors affecting subcontractors' productivity in Iran. The top factors included: shortage of materials and tools, poor planning, rework, poor supervision, weather and poor site conditions. Mahamid (2013) conducted a study to investigate the main factors affecting labor productivity in public projects. He found that the top five factors were: political situation, shortage in equipment, old equipment, lack of experience, and poor management on sites. Jarkas \& Bitar (2012) found that the top five factors affecting construction productivity in Kuwait were: specifications clarity, frequent change orders, poor coordination between designers, poor supervision, and poor subcontractors.

\section{Rework on construction sites}

Rework is simply defined as the process when completed work does not conform to specifications (Oyewobi et al., 2011). McDonald (2013) defined rework as "work measures that have to be completed more than once". Love et al. (2000) identified rework as the "unnecessary effort of redoing a process or activity that was incorrectly implemented the first time". Enshassi et al. (2009) stated that rework is a critical problem in construction industry that leads to cost overrun, schedule delay and customer dissatisfaction. Oyewobi et al. (2011) revealed that the rework cost for new building is about $5.06 \%$ of their contract values. Barber et al. (2000) pointed that rework costs could be as high as $23 \%$ of the contract value. Many studies, which were investigated rework on construction sites, revealed that rework increased the cost of the different work elements between $3 \%$ to $30 \%$ and caused delays in the different work elements leading to the increase of their original durations from $10 \%$ to $77 \%$. In addition, rework caused clients' and contractors dissatisfaction (Wasfy, 2010). According to Love and Edwards (2004), the main causes of rework can be grouped into three different sources: 1) client-related, 2) design-related and 3) contractor-related factors. Palaneeswaran (2006) indicated that rework in building works is more predominate due to different interface-related management issues such as poor communication between construction parties during design phase and poor coordination between building contractors and building services. Enshassi et al. (2017) concluded that the main rework causes on construction sites in Gaza were: fraud, competitive pressure, ineffective management, schedule 
pressure and the absence of job security. Hwang et al. (2009) showed that the main rework causes on construction sites included: owner change, design errors, constructor errors.

Oyewobi et al. (2011) concluded that rework causes in building projects included: error in design, construction failure, frequent change orders, and poor coordination and communication between construction parties. Ye et al. (2014) carried out a questionnaire survey to investigate rework causes on construction sites in China. They concluded that the top rework causes were: poor construction materials, unclear project process management, and poor quality of construction technology. Toole (2005) indicated that excessive overtime has negative impact on productivity and quality and leads to rework on construction sites. Palaneeswaran (2006) concluded that rework has direct and indirect impacts on construction performance. According to Palaneeswaran et al. (2005), some of direct impacts include: (1) schedule delay, (2) cost overrun, (3) additional materials for rework and wastage, and (4) increase in labor cost to fix the defect. Some of indirect impacts are: poor moral, profit reduction, loss of future work, fatigue, stress, conflicts, end-user dissatisfaction, de-motivation, and absenteeism (Love, 2002). Mahamid (2016) conducted a study to identify the main rework causes in residential buildings. He concluded that the top causes were: poor communication and coordination between construction parties, material quality, and poor site management. Wasfy (2010) conducted a study in Saudi Arabia to address the main rework causes in construction projects. He found that the most severe factors included: poor supervisors, lack of supervisors, lack of labor experience, poor subcontractors, and improper work protection. Mahamid (2017) indicated that the main rework causes in highway projects were: non-conformance with specification, scope changes by owner, poor labor skills, improper subcontractor selection, and late changes.

In summary, many previous studies were conducted to identify factors affecting labor productivity and rework causes in construction projects. However, very limited or no literatures investigated the impact of rework on labor productivity. This study was conducted to address the relationship between labor productivity and rework on construction sites.

\section{Methodology}

The following methods were used in this study:

1) Questionnaire survey - stage 1: a questionnaire survey was carried out to identify the main factors affecting labor productivity and the main causes of rework on construction sites (more details in section 3.1)

2) Questionnaire survey - stage 2: Eigen values was used to identify the significant rework causes, then a questionnaire survey was conducted to address the impact of these causes on labor productivity (more details in section 3.3)

3) Data analysis: this section includes 3 subsections, they are: factors ranking, Spearman ran correlation, and prediction models. (more details in section 3.3).

\section{Questionnaire survey}

The questionnaire is divided into three main sections. The questionnaire sections were as follow: Section 1: this section asked for information about the respondent and the company (i.e. occupation, level, experience, staff, size). Section 2: it included the list of factors affecting labor productivity according to literature review and opinion of local experts. Section 3: it included rework causes as identified from literature review and opinions of local experts. 18 factors affecting labor productivity and 20 factors affecting rework are tabulated in the questionnaire. Respondents were asked to identify the impact level of each factor using an ordinal five-point scale as follow: 1 indicates very low impact, 2 indicates low impact, 3 indicates medium impact, 4 indicates high impact and 5 indicates very high impact.

A draft questionnaire was sent to some local construction experts to test the validity and suitability of the questions and to suggest any needed changes. Slight changes were done according to their feedback.

\section{Study population}

The target population included: 1) the total number of building contractors (grade 1, 2, and 3) who have valid registration in the Palestinian Contractors Union, 2) the total number of consultants who are involved in the building projects and have a valid membership in the Engineering Association in the West Bank and. The registered contractors are 212 and the registered consultants are 106. To compute the sample size that represents the total population, the following equation was used (Emory, 1980):

$$
\mathrm{n}=(\mathrm{ts} / \mathrm{d})^{2} /\left[1+(\mathrm{ts} / \mathrm{d})^{2} / \mathrm{N}\right] \quad \text { Equation (1) }
$$


where,

$\mathrm{n}$ = sample size

$\mathrm{N}=$ sample of population

$t=$ abscissa of the normal curve that cuts of an area of $\alpha=0.01$ at the tails $(t=2)$

$d=$ expected error in the estimate $(d=0.01)$

$\mathrm{s}=$ max. standard deviation in proportion of estimation $=\mathrm{P} \times \mathrm{q}($ at $\mathrm{P}=0.5$ and $\mathrm{q}=1-\mathrm{P}=0.5)$

Equation 1 was used to compute the representative number of contractors and consultants (Table 1). Calculations stopped when the difference between $n$ and $n-1$ is insignificant.

\begin{tabular}{ccc} 
Table 1. Summary of sample size calculation & trials. Source: Self-elaboration. \\
\hline $\mathrm{n}_{0}$ & $\begin{array}{c}\text { Population } \\
\text { (contractors) }\end{array}$ & $\begin{array}{c}\text { Population } \\
\text { (consultants) }\end{array}$ \\
$\mathrm{n}_{1}$ & 912 & 102 \\
$\mathrm{n}_{2}$ & 57 & 62 \\
$\mathrm{n}_{3}$ & 42 & 45 \\
$\mathrm{n}_{4}$ & 33 & 35 \\
$\mathrm{n}_{5}$ & 27 & 29 \\
$\mathrm{n}_{6}$ & 23 & 22 \\
$\mathrm{n}_{7}$ & 20 & 19 \\
$\mathrm{n}_{8}$ & 18 & 17 \\
\hline
\end{tabular}

Results show that at least 20 contractors and 17 consultants should be involved in the questionnaire so that the sample size represents the total population. For instance, for more accurate results, the questionnaire was sent randomly to 40 consultants and 50 contractors. 38 contractors (out of 50; response rate $=76 \%$ ) and 30 consultants (out of 40 ; response rate $=75 \%$ ) completed the questionnaire. The respondents were experienced managers, engineers, and planners. The average experience of the respondents is greater than 10 years.

\section{Data analysis}

\section{Factors ranking}

After receiving the filled questionnaires (stage 1), Excel statistical tools were used to analyze the data. The identified factors were ranked using the weighted mean. Then, the most significant factors were identified using factor analysis such that: factors with Eigen value greater or equal to 1 (significant factors) were retained and factors with Eigen value less than 1 (insignificant factors) were dropped. After identifying the significant rework causes, a questionnaire survey (stage 2) was performed to address the impact of these causes on labor productivity.

\section{Spearman rank correlation}

This test is used to find the degree of agreement between contractors and consultants on the ranking of the factors affecting labor productivity and rework causes. A value of +1 means a perfect positive correlation between responses and a value of -1 indicates a perfect negative correlation. To calculate the values of Spearman rank correlation coefficient $\left(r_{s}\right)$, Equation (2) was used (Harnett \& Murphy, 1975):

$$
r_{s}=1-\left[6 * \sum d^{2} /\left(n^{3}-n\right)\right] \quad \text { Equation (2) }
$$

where; $r_{s}=$ Spearman rank correlation coefficient.

$d=$ difference between ranks on one variable and ranks on the other variable

$n=$ number of causes

\section{Prediction models}

One of the study objectives was to address the relation between rework and labor productivity in building construction projects. To achieve this objective, data from 40 building construction projects. The data included records for rework cost and labor productivity of some finishing works (plastering, ceramic works, and brick works). The projects were implemented in the West Bank in Palestine between 2015 and 2018. The data were collected form contracting firms specialized in building construction. 
Linear regression analysis was selected to develop the prediction models. Linear regression models were used to describe the linear combination between dependent and independent variables. The variables to be included in the models were defined as follow: "labor productivity" as dependent variable and "rework cost" as independent variable. (discussed in detail in section 4.5).

\section{Results and Discussion}

\section{Ranking of factors affecting labor productivity}

Table 2 presents the ranking of factors affecting labor productivity from contractors' and consultants' perspective. Eighteen (18) factors were identified through literature review and opinions of local experts. The identified factors were ranked by the respondents according to their negative impact on labor productivity. 5-points Likert scale (1-5) was used for ranking.

Results indicated that the top 5 factors affecting labor productivity from contractors' point of view are: lack of labor experience, payments delay, rework due to labor mistakes, lack of supervisor's experience and lack of coordination between construction parties. Consultants responses identified the following factors as top 5 factors: payments delay, rework due labor mistakes, lack of labor experience, materials shortage and low wages. Overall, results indicated that the top 5 factors are: lack of labor experience, payments delay, rework due to labor mistakes, lack of supervisor's experience and materials shortage.

Results are in line with similar previous studies. For example, "lack of labor experience" concluded as a top factor affecting labor productivity by Mahamid et al. (2014), Mahamid (2018), and Robles et al. (2014). Mahamid et al. (2014) concluded that "payments delay" is one of the main factors affecting labor productivity. Bekr (2016) found that "rework due to labor mistakes", "lack of supervisors experience" and "material shortage" are significant factors affecting construction productivity. Ghoddousi \& Hosseini (2012), Robles et al. (2014), and Mahamid (2018) indicated that "material shortage" is one of the critical factors affecting labor productivity on construction sites.

Table 2. Ranking of factors affecting labor productivity in building projects. Source: self-elaboration.

\begin{tabular}{|c|c|c|c|c|c|c|}
\hline \multirow[b]{2}{*}{ Factor } & \multicolumn{2}{|c|}{ Contractor view } & \multicolumn{2}{|c|}{ Consultant view } & \multicolumn{2}{|c|}{ Overall } \\
\hline & Mean & Rank & Mean & Rank & Mean & Rank \\
\hline Lack of labor experience & 3.97 & 1 & 3.92 & 3 & 3.95 & 1 \\
\hline Payments delay & 3.83 & 2 & 4.04 & 1 & 3.92 & 2 \\
\hline Rework due to labor mistakes & 3.72 & 3 & 3.95 & 2 & 3.83 & 3 \\
\hline Lack of supervisor's experience & 3.51 & 4 & 3.57 & 6 & 3.54 & 4 \\
\hline Materials shortage & 3.28 & 6 & 3.75 & 4 & 3.49 & 5 \\
\hline $\begin{array}{l}\text { Lack of coordination between } \\
\text { construction parties }\end{array}$ & 3.41 & 5 & 3.49 & 7 & 3.45 & 6 \\
\hline Low wages & 3.11 & 7 & 3.62 & 5 & 3.34 & 7 \\
\hline $\begin{array}{l}\text { Misunderstanding between } \\
\text { labors and superintendents }\end{array}$ & 2.92 & 10 & 3.33 & 8 & 3.10 & 8 \\
\hline Equipment shortage & 3.05 & 8 & 3.11 & 10 & 3.08 & 9 \\
\hline $\begin{array}{l}\text { Unsuitable materials storage } \\
\text { location }\end{array}$ & 2.91 & 11 & 3.25 & 9 & 3.06 & 10 \\
\hline $\begin{array}{l}\text { Lack of financial motivation } \\
\text { system }\end{array}$ & 2.97 & 9 & 2.98 & 11 & 2.98 & 11 \\
\hline Inspection delay & 2.87 & 12 & 2.80 & 13 & 2.84 & 12 \\
\hline $\begin{array}{l}\text { Bad relations between labors } \\
\text { and management team }\end{array}$ & 2.83 & 13 & 2.75 & 14 & 2.79 & 13 \\
\hline Labor personal problems & 2.74 & 16 & 2.85 & 12 & 2.79 & 14 \\
\hline Labor absenteeism & 2.69 & 17 & 2.65 & 15 & 2.67 & 15 \\
\hline Working within a confined space & 2.78 & 15 & 2.52 & 17 & 2.66 & 16 \\
\hline Misuse of time schedule & 2.82 & 14 & 2.44 & 18 & 2.65 & 17 \\
\hline Overmanning & 2.67 & 18 & 2.58 & 16 & 2.63 & 18 \\
\hline
\end{tabular}




\section{Ranking of rework causes}

Twenty (20) rework causes were identified from literature review and local experts' feedback. Respondents ranked these causes according to their impact level on rework. 5-points Likert scale was used to obtain the view of respondents. Results are shown in Table 3.

Contractors ranked the top 5 factors as follow: lack of manpower skills, non-compliance with specifications, inadequate coordination and integration, frequent change orders and inadequate job planning. Consultants input indicated that the top 5 rework causes are: inadequate coordination and integration, inadequate job planning, lack of manpower skills, non-compliance with specifications and errors and omissions. Overall view reveled that the top 5 rework causes are: lack of manpower skills, non-compliance with specifications, frequent change orders, inadequate job planning, and inadequate coordination and integration. The results agree with previous studies. For example, "lack of labor skills" is concluded by Wasfy (2010) and Mahamid (2017) as a top rework cause. "Non-compliance with specifications" concluded by Mahamid (2017) as a critical rework cause. Enshassi et al. (2017) found that "poor planning" is one of the top rework causes. "Late changes" is one of the significant rework causes as concluded by Hwang et al. (2009), Mahamid (2017), and Oyewobi et al. (2011).

Factor analysis was performed to address the most significant rework causes. Only causes with Eigen value $\geq 1.0$ were retained. Results indicate four (4) key causes (Eigen value ranging from 1.008 for last one to 4.326 for top one). These causes are: namely: lack of manpower skills, non-compliance with specifications, frequent change orders, and inadequate job planning. The key causes accounted for a cumulative variance of $70.05 \%$.

Table 3. Contractors' and consultants' perception of rework causes in building projects. Source: self-elaboration.

\begin{tabular}{|c|c|c|c|c|c|c|}
\hline \multirow[b]{2}{*}{ Cause } & \multicolumn{2}{|c|}{ Contractor } & \multicolumn{2}{|c|}{ Consultant } & \multicolumn{2}{|c|}{ Overall } \\
\hline & Mean & Rank & Mean & Rank & Mean & Rank \\
\hline Lack of manpower skills & 4.18 & 1 & 3.87 & 3 & 4.04 & 1 \\
\hline Non-compliance with specifications & 4.13 & 2 & 3.76 & 4 & 3.96 & 2 \\
\hline Frequent change orders & 3.82 & 4 & 4.06 & 1 & 3.93 & 3 \\
\hline Inadequate job planning & 3.64 & 5 & 4.00 & 2 & 3.80 & 4 \\
\hline $\begin{array}{l}\text { Inadequate coordination and } \\
\text { integration }\end{array}$ & 3.88 & 3 & 3.62 & 6 & 3.76 & 5 \\
\hline Errors and omissions & 3.54 & 7 & 3.73 & 5 & 3.63 & 6 \\
\hline Improper contractor selection & 3.60 & 6 & 3.46 & 9 & 3.54 & 7 \\
\hline Scope changes & 3.37 & 9 & 3.57 & 7 & 3.46 & 8 \\
\hline Poor site management & 3.33 & 10 & 3.48 & 8 & 3.40 & 9 \\
\hline Labors re-allocation to other projects & 3.43 & 8 & 3.30 & 10 & 3.37 & 10 \\
\hline Unclear work specifications & 3.15 & 13 & 3.16 & 11 & 3.16 & 11 \\
\hline Use of inefficient equipment & 3.24 & 12 & 2.99 & 14 & 3.13 & 12 \\
\hline Late design changes & 3.10 & 14 & 3.12 & 12 & 3.11 & 13 \\
\hline Inadequate supervision & 3.29 & 11 & 2.85 & 15 & 3.10 & 14 \\
\hline Poor project document & 2.96 & 15 & 3.08 & 13 & 3.01 & 15 \\
\hline Lack of employee motivation & 2.90 & 16 & 2.72 & 17 & 2.82 & 16 \\
\hline Poor site conditions & 2.77 & 18 & 2.74 & 16 & 2.76 & 17 \\
\hline Lack of supervisory skills & 2.82 & 17 & 2.66 & 18 & 2.75 & 18 \\
\hline Excessive overtime & 2.49 & 20 & 2.63 & 19 & 2.55 & 19 \\
\hline $\begin{array}{l}\text { Errors due to inappropriate construction } \\
\text { method }\end{array}$ & 2.60 & 19 & 2.46 & 20 & 2.54 & 20 \\
\hline
\end{tabular}

\section{Spearman rank correlation}

Equation (2) was used to test the agreement between contractors and consultants on the importance of the factors affecting labor productivity and rework causes on construction sites. The results show a good correlation between the respondents on the importance of labor productivity factors and rework causes with $r_{s}$ value of 0.82 and 0.78 , respectively. This result indicates that the study is reliable. 


\section{Rework and labor productivity on construction sites}

The impact of four key rework causes (causes with eigen value $\geq 1.0$ ) on labor productivity was ranked according to respondents' point of view. Table 4 shows the impact of these causes in relative ranks. Results show that the factor with highest impact on labor productivity is "lack of manpower skills". $80 \%$ of responses rated this factor as a top affecting factor. This is followed by "non-compliance with specifications", "frequent change orders" and "inadequate job planning". These factors received response of $73 \%, 72 \%$ and $66 \%$ on account of high impact on labor productivity, respectively. The results reveal that the four key rework causes have high impact on labor productivity on construction sites. Therefore, attention should be paid to control these causes to improve project performance in terms of reducing rework cost and increasing labor productivity.

Lack of manpower experience leads to labor mistakes, misunderstanding of drawing and specification, misuse of available resources. This resulted in rework and loss in productivity. "non-compliance with specifications" comes from several reasons such as: labor mistakes, lack of understanding of contract documents, unclear specifications, lack of experience. Specifications should be written in clear and well from, such that it can be well understood. Training workshops should be performed for labors to increase their experience and site superintendents to have better understanding for contract documents. Inadequate job planning could be due to poor communication and coordination between construction parties during different phases of project, and this affect progress flow and lead to late changes that lead to rework and loss in productivity.

The results reveal that the four key rework causes have high impact on labor productivity on construction sites. Therefore, attention should be paid to control these causes to improve project performance in terms of reducing rework cost and increasing labor productivity.

Table 4. Relationship between rework and labor productivity in building projects. Source: self-elaboration.

\begin{tabular}{lcccccc}
\hline \multicolumn{1}{c}{ Significant rework causes } & \multicolumn{7}{c}{ Impact on labor productivity } \\
\cline { 2 - 7 } \multicolumn{1}{c}{ (Eigen values $\geq 1.0$ ) } & $\begin{array}{c}\text { No } \\
\text { impact }\end{array}$ & $\begin{array}{c}\text { Low } \\
\text { impact }\end{array}$ & $\begin{array}{c}\text { Moderate } \\
\text { impact }\end{array}$ & $\begin{array}{c}\text { High } \\
\text { impact }\end{array}$ & $\begin{array}{c}\text { Extreme } \\
\text { impact }\end{array}$ & $\begin{array}{c}\text { Relative } \\
\text { index }\end{array}$ \\
\hline Lack of manpower skills & 0 & 2.02 & 18.3 & 56.78 & 22.9 & 0.60 \\
Non-compliance with & 0 & 3.57 & 23.2 & 59.73 & 13.5 & 0.57 \\
specifications & & & & & & \\
Frequent change orders & 0 & 4.1 & 22.55 & 60.75 & 12.6 & 0.56 \\
Inadequate job planning & 0 & 5.5 & 27.7 & 61.7 & 5.1 & 0.53 \\
\hline
\end{tabular}

\section{Predictive models describing the relation between rework and labor productivity}

One of the study objectives was to address the relationship between rework and labor productivity in building construction projects. To achieve this objective, needed data were gathered from 40 building projects implemented in the West Bank in Palestine. Regression analysis was used to establish the required models. In the developed models, the dependent variable is labor productivity and the independent variable is rework cost. Equation 3 shows the standard form linear regression models:

$$
Y=\alpha+\beta X \quad \text { Equation (3) }
$$

where:

$Y=$ Rework cost $(\%$ of item contract price)

$\mathrm{X}=$ labor productivity

$\alpha=$ intercept

$\beta=$ coefficient of rework cost

Three (3) predictive models were developed; each one described the relation between labor productivity and rework cost in a specified activity, namely: plastering, ceramic works, and block works. Details are shown in the following sections. 


\section{Model 1: predictive model of rework impact on labor productivity in plastering}

To establish a mathematical model that relate rework and labor productivity in plastering works, data from 40 building projects was used. The data indicated that the average of rework cost in plastering is $5.11 \%$ and the average of labor productivity is $30.59 \mathrm{~m}^{2} /$ day (productivity for 2 labors crew). Figure 1 shows the linear regression model that describe the impact of rework on labor productivity in plastering. Table 4 shows the results of regression analysis. The table shows that $\mathrm{R}^{2}=0.82, \mathrm{~F}_{(1,39)}=68.24$, and $\mathrm{p}=0.00$; indicating that the model can well predict the impact of rework on labor productivity. The model indicate that labor productivity decreases by 2.02 for 1 unit increase in rework cost. The model is presented in Equation (4):

$$
Y=40.9-2.02 X \quad \text { Equation (4) }
$$

Where; $Y$ is labor productivity in plastering $\left(\mathrm{m}^{2} /\right.$ day), $\mathrm{X}$ is rework cost in plastering (\%).

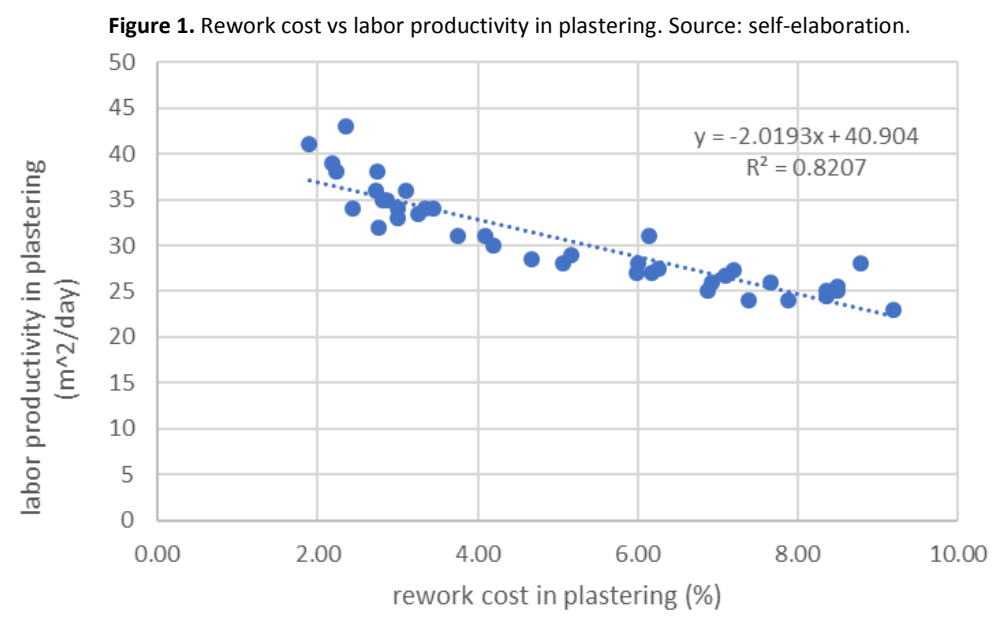

Table 4. Regression statistics for Equation 4. Source: elf-elaboration.

\begin{tabular}{|c|c|c|c|c|c|}
\hline Regression Statistics & & & Coefficients & t Stat & P-value \\
\hline R Square & 0.82 & Intercept & 40.9 & 6.39 & 0.00 \\
\hline Observations & 40 & Rework cost in plastering (\%) & -2.02 & 7.88 & 0.00 \\
\hline$F$ & 68.24 & & & & \\
\hline
\end{tabular}

\section{Model 2: predictive model of rework impact on labor productivity in brick works}

Figure 2 shows the relationship between rework cost and labor productivity in brick works. Figure 2 indicates inverse relationship between them: the higher rework cost the lower productivity. The results show that the percentage of average rework cost in brick works is 4.51 and the average labor productivity is $26.2 \mathrm{~m}^{2} /$ day (for 2 labor crew). The developed model that describes the impact of rework cost on labor productivity in brick works is shown in Equation (3). Table 5 shows the statistical analysis for Equation (5): $R^{2}=0.78, F_{(1,39)}=62.71$, and $p=0.00$; indicating good correlation between the dependent and independent variables. The model indicates that labor productivity decreases by 1.71 unit for 1 unit increase in rework cost.

$$
Y=34.36-1.71 X \quad \text { Equation (5) }
$$

were: $\mathrm{Y}$ is labor productivity in brick works $\left(\mathrm{m}^{2} /\right.$ day), $\mathrm{X}$ is rework cost in brick works (\%).

\begin{tabular}{|c|c|c|c|c|c|}
\hline Regression Statistics & & & Coefficients & t Stat & P-value \\
\hline R Square & 0.78 & Intercept & 34.36 & 7.11 & 0.00 \\
\hline Observations & 40 & Rework cost in brick works (\%) & -1.71 & 6.44 & 0.00 \\
\hline$F$ & 62.71 & & & & \\
\hline
\end{tabular}

Table 5. Regression statistics for Equation 5. Source: self-elaboration. 
Figure 2. Rework cost vs labor productivity in brick works. Source: self-elaboration.

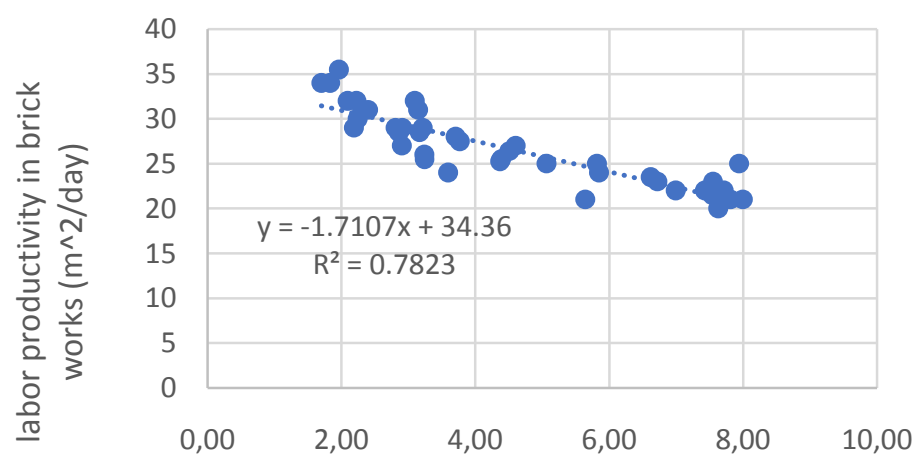

rework cost in brick works (\%)

\section{Model 3: predictive model of rework impact on labor productivity in ceramic works}

Figure 3 shows the relationship between rework cost and labor productivity in ceramic works. It indicates inverse relationship between them: the higher rework cost the lower productivity. The results show that the percentage of average rework cost in ceramic works is 5.43 and the average labor productivity is $30.55 \mathrm{~m}^{2} /$ day (for 2 labor crew). The developed model that describes the impact of rework cost on labor productivity in ceramic works is shown in Equation (4). Table 6 shows the statistical analysis for Equation (6): $R^{2}=0.79, F_{(1,39)}=64.15$, and $p=0.00$; indicating good correlation between the dependent and independent variables. The model shows that labor productivity decreases by 2.58 unit for 1 unit increase in rework cost.

$$
Y=44.60-2.58 X \quad \text { Equation (6) }
$$

where: $\mathrm{Y}$ is labor productivity in ceramic works ( $\mathrm{m}^{2} /$ day), $\mathrm{X}$ is rework cost in ceramic works (\%).

Figure 3. Rework cost vs. labor productivity in ceramic works. Source: self-elaboration.

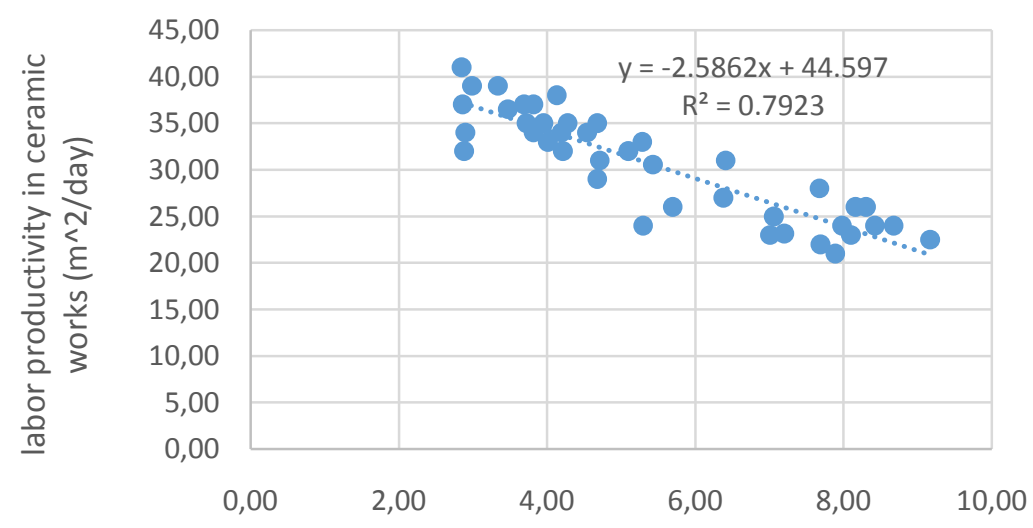

reowrk cost in ceramic works (\%)

Table 4. Regression statistics for Equation 6. Source: self-elaboration.

\begin{tabular}{|c|c|c|c|c|c|}
\hline \multirow[b]{2}{*}{ Regression Statistics } & & & \multicolumn{2}{|c|}{ Coefficient } & \multirow[b]{2}{*}{ P-value } \\
\hline & & & $s$ & t Stat & \\
\hline R Square & 0.79 & Intercept & 44.60 & 5.89 & 0.00 \\
\hline Observations & 40 & Rework cost in ceramic works (\%) & -2.58 & 6.02 & 0.00 \\
\hline$F$ & 64.15 & & & & \\
\hline
\end{tabular}


This study was conducted to address the relationship between rework cost and labor productivity in building construction projects in the West Bank in Palestine. The study concluded that the top five factors affecting labor productivity were: lack of labor experience, payments delay, rework due to labor mistakes, lack of supervisor's experience and materials shortage. The study also showed that the top five rework causes in building projects were: lack of manpower skills, non-compliance with specifications, frequent change orders, inadequate job planning, and inadequate coordination and integration. The results of Spearman rank correlation test indicated a good correlation between the respondents on the importance of labor productivity factors and rework causes with $r_{s}$ value of 0.82 and 0.78 , respectively. This implies that the study is reliable.

Based on data collected from 40 building construction projects implemented in Palestine, predictive models that described the relationship between rework and labor productivity were developed. Three (3) models were developed: rework versus labor productivity in plastering, rework versus labor productivity in brick works, and rework versus labor productivity in ceramic works. The results indicated that rework has a significant impact on labor productivity in building projects. Rework and labor productivity have an inverse relationship. i.e. the higher the rework cost the lower the labor productivity.

Based on the results of the study, the following points were recommended to minimize rework and improve labor productivity on construction sites: (1) labors should have workshops to improve their skills; technical skills and managerial skills as well, (2) specifications should be clear, well written, and carefully read during bidding phase to avoid conflicts during construction phase, (3) construction parties should have more communication and coordination during the early project phases to minimize late changes during construction, (4) payments should be paid on time to maintain the smooth progress of the project, (5) construction parties should prepare a well-defined plan for job doing.

References

Anyur, K., Serdad, U., Turgut, A. \& Bayram, E. (2016). Factors affecting labor productivity: perspectives of craft workers. Creative Construction Conference, 25-28 June, Budapest, Hungarey.

Barber, P., Sheath, D., Tomkins, C., \& Graves, A. (2000). The cost of quality failures in major civil engineering projects. Int. J. Quality Reliability Manage., 17(4/5), 479-492.

Bekr, G. (2016). Study of Significant Factors Affecting Labor Productivity at Construction Sites in Jordan: Site Survey. Journal of Engineering Technology (JET), 4(1), $92-97$.

Chandrusha, S. \& Basha, M. (2017). Rework Management in Construction Projects and Comparison with Time and Cost. International Journal of Engineering Science and Computing, 7(6), 13020-13025.

El-Gohary, K. \& Aziz, R. (2014). Factors influencing construction labor productivity in Egypt. Journal of Management in Engineering, 30, 1-9.

Emory, C. (1980). Business Research Methods. Revised Edition, Richard D. Irwin, Homewood, IL.

Enshassi, A., Al-Najjar, J., \& kumaraswamy, M. (2009). Delays and cost overruns in construction projects in the Gaza Strip. Journal of Financial Management of Property and Construction, 14(2),126-251.

Enshassi, A., Sundermeier, M., \& AboZeiter, M. (2017). Factors Contributing to Rework and their Impact on Construction Projects Performance. International Journal of Sustainable Construction Engineering \& Technology, 8(1).

Ghoddousi, P. \& Hosseini, M. (2012) A survey of the factors affecting the productivity of construction projects in Iran. Journal of Technological and Economic Development of Economy, 18(1),99-116.

Harnett, D. \& Murphy, J. (1975), Introductory Statistical Analysis. Addison-Wesley Publishing.

Hwang, B., Thomas, S., Haas, C., \& Caldas C. (2009). Measuring the Impact of Rework on Construction cost Performance. Journal of Construction Engineering and Management, 135(3), 187-198.

Jarkas, A. \& Bitar, C. (2012). "Factors affecting construction labor productivity in Kuwait." Journal of Construction Engineering and Management, 138(7), 811-820.

Kaming, P., Olomolaiye, P., Holt G., \& Harris F. (1997). Factor influencing construction time and cost overruns on high-rise Projects in Indonesia. Constr. Mgt. Econ., 15, 83-94.

Liu, M. \& Ballard, G. (2008) Improving labor productivity through production control. Proceedings of the 11th Annual Conference of International Group for Lean Construction, Manchester, UK.

Love P., Mandal P., Smith J., \& Georgiou J. (2000). DECOEM: A Design and Construction Rework Minimization Model. 1st International Conference on Systems Thinking in Management. 
Love, P. (2002). Auditing the indirect consequences of rework in construction: A case-based approach. Managerial Auditing Journal, 17(3),138-146.

Love, P. \& Edwards, D. (2004). Determinants of rework in building construction projects. Journal of Engineering, Construction and Architectural Management, 11(4), 259-274.

Mahamid, I. (2013). Principal Factors Impacting Labor Productivity of Public Construction Projects in Palestine: Contractors' Perspective. International Journal of Architecture, Engineering and Construction (IJAEC), 2(3),194 - 202.

Mahamid, I. (2016). Analysis of Rework in Residential Building Projects in Palestine. Jordan Journal of Civil Engineering, 10(2), $197-208$.

Mahamid, I. (2017). Effect of change orders on rework in highway Projects in Palestine. Journal of Financial Management of Property and Construction, 22(1), 62-76.

Mahamid, I. (2018). Study of the relationship between cost overrun and labor productivity in road construction projects. International Journal of Productivity and Quality Management, 24(2),143 - 164.

Mahamid, I., Alghonamy, A. \& Aichouni, M. (2014) Major factors influencing employee productivity in the KSA public construction projects. International Journal of Civil and Environmental Engineering, 14(1),16-20.

McDonald, R. (2013). Root causes and consequential cost of rework. XL Group Insurance, North America Construction. Available at: http://xlgroup.com/ /media/1048e70923e549b49905d503c19abf14.pdf (Accessed 30 Sep. 2018).

Montaser, N., Mahdi, I., Mahdi, H. \& Abdul Rashid, I. (2018). Factors affecting construction labor productivity for construction of pre-stressed concrete bridges. International Journal of Construction Engineering and Management, 7(6), 193-206.

Moselhi, O. and Khan, Z. (2012). Significance ranking of parameters impacting construction Labour Productivity. Construction Innovation -emerald insight, Howard House Wagon Lane Bingley BD16 1WA United Kingdom, 12 (3), 272 - 296.

Nadia, J., Rateb, J., Ghaith, K., Amr, E., Diana, A. \& Ghaleb, J. (2017). Demotivating factors influencing productivity in Jordanian residential construction projects. Int. J. of Productivity and Quality Management, Vol. 20(2),154-168, DOI: http://dx.doi.org/10.1504/IJPQM.2017.10002162.

Navon, R. (2005). Automated project performance control of construction projects. Automation in Construction 14, 467-476.

Oyewobi, L., Oke, A, Ganiyu, B., Shittu, A., Isa, R., \& Nwokobia, L. (2011). The effect of project types on the occurrence of rework in expanding economy. Journal of Civil Engineering and Construction Technology, 2(6), 119-124.

Palaneeswaran, E. (2006). Reducing rework to enhance project performance levels. Proceedings of the one-day seminar on recent developments in project management in Hong Kong, Centre for Infrastructure and Construction Industry Development, Hong Kong, pp.5.1-5.10.

Palaneeswaran, E., Kumaraswamy, M., Ng, T., \& Love, P. (2005). Management of Rework in Hong Kong Construction Projects. Conference Proceedings, The Queensland University of Technology Research Week International Conference, July 4-5.

Robles, G., Stifi, A., Ponz-Tienda, J., \& Gentes, S. (2014). Labor productivity in the construction industry-factors influencing the spanish construction labor productivity. International Journal of Civil and Environmental Engineering, 8(10), 1061-1070.

Toole, T. (2005). A Project Management Causal Loop Diagram. ARCOM Conference, London, UK, Sep 5-7.

Wasfy, M. (2010). Severity and impact of rework, a case study of a residential commercial tower project in the Eastern Province-KSA. Master thesis, KFUPM, Dhahran, KSA. Available online: https://faculty.kfupm.edu.sa/CEM/soliman/CEM600/CEM\%20600\%20Report-Moataz\%20Wasfy.pdf.

Ye, G., Jin, Z., Xia, B., \& Skitmore, M. (2014). Analyzing causes for reworks in construction projects in China. ASCE Journal of Management in Engineering, 10, 1061. 